\title{
Niewygłoszona homilia tęczowego księdza. Recenzja monodramu Wyznania OT Rondo w Słupsku
}

https://doi.org/10.51897/interalia/OBLL2427

Mateusz Marecki

Jilin University, China

Reżyseria i scenariusz: Stanisław Otto Miedziewski

Głosu użyczyła Agata Andrzejczuk

Koncepcja światet i opracowanie dźwiękowe: Maciej Sierosławski

Plakat: Piotr Igor Salata

Grafika: Beata Samborska

Monodram Wyznania Ośrodka Teatralnego RONDO w Słupsku - w reżyserii Stanisława Otto Miedziewskiego, z Grzegorzem Piekarskim w roli głównej i jedynej - stwarza unikalną szansę. Daje możliwość uczestniczenia w mszy świętej, podczas której ksiądz ją prowadzący robi coming out, obnaża hipokryzję i nadużycia instytucji, której jest częścią, oraz mówi bez ogródek o swoim zagubieniu emocjonalnym. Wpisuje się tym samym w rodzący się kanon przedsięwzięć artystycznych podejmujących temat trudnej, toksycznej i przemocowej relacji Kościół-społeczność LBGTI z perspektywy mało znanej - homoseksualnego księdza, który niczym koń trojański przedstawia swoją wersję konfliktu z wewnątrz paszczy lwa.

Przywodzi choćby na myśl wyróżniony nagrodą Teddy film W imię (2013), w reżyserii Małgorzaty Szumowskiej, który opowiada historię duchownego (w tej roli Andrzej Chyra) uciekającego od prawdy o swojej seksualności w wiarę. Ostatecznie nie dochodzi jednak - jak w słupskim monodramie - do coming outu, los księdza pozostaje nieujawniony, a jego kochanek wstępuje do seminarium, co sugeruje, że ta historia będzie się powtarzać w nieskończoność. Kluczowy dla Wyznań w reżyserii Miedziewskiego wątek nieheteronormatywnej seksualności duchownego katolickiego jest w filmie Szumowskiej potraktowany subtelnie, przy użyciu aluzji i niedomówień. $W$ imię nie wikła się w politykę, nie jest też głosem w debacie o systemowej homofobii Kościoła katolickiego - to przede wszystkim uniwersalna historia o wykluczeniu.

W Wyznaniach Miedziewskiego można się też doszukiwać nawiązań do głośnego medialnego show księdza Krzysztofa Charamsy, który w 2015 podjął samozwańczą (i zakończoną spektakularnym niepowodzeniem) batalię o odnowę Kościoła katolickiego i zaprezentował światu swojego narzeczonego, żądając od hierarchów kościelnych większej tolerancji wobec mniejszości seksualnych i poparcia dla małżeństw jednopłciowych, czym wzbudził w Polsce skrajne reakcje. Duchowny był jednocześnie celebrowany i potępiany, jakby opinia publiczna nie była w stanie zdecydować, jak odczytywać jego 
ujawienie jako geja. Kontrowersje, także wśród tzw. liberalnych mediów i - jak ich określa dwumiesięcznik Replika - pseudosojuszników społeczności LGBTI, wywołał też styl księdza Charamsy - konfrontacyjny, bezkompromisowy i obsceniczny, tym samym stojący w sprzeczności z oficjalną kościelną doktryną skromności i pokory. Taka postawa została uznana za narcystyczną i niestosowną przez komentatorów, którzy być może byliby skłonni rozważyć przyznanie równych praw osobom LGBTI, ale tylko jeśli ci dostosują się do schematu zachowań i reguł gry narzuconych przez liberalną elitę.

Prawdopodobna wydaje się też inspiracja mniej głośnym, ale za to entuzjastycznie przyjętym monodramem Wściekły pies w reżyserii Dariusza Jezierskiego, wystawionym w 2010 roku w katowickim Teatrze Kortez przez gliwicką grupę teatralną Teatr Nowej Sztuki. Ta adaptacja reportażu Wojciecha Tochmana pod tym samym tytułem stawia widzów w roli spowiedników księdza, który doświadcza kryzysu tożsamości spowodowanego własną odmiennością seksualną. Będąc rozdartym między służbą Bogu a słabością do mężczyzn, szuka - jak pisze w swojej recenzji Dariusz Korytko (Gazeta Wyborcza Katowice nr 14, 2010) - „zaspokojenia w nocnych klubach dla gejów. A potem podnosi na mszy hostię, która w jego dłoniach wydaje się coraz cięższa. A mimo to rozdaje komunię, przypominając wiernym, że to Ciało Chrystusa".

Analogii do Wściekłego psa w słupskim monodramie według scenariusza Miedziewskiego można znaleźć sporo na poziomie narracji. Oba spektakle mają prowokować i budować napięcie poprzez swobodne przejścia pomiędzy sferą sacrum i profanum, poprzez przeplatanie uduchowionych wywodów gęstych od nawiązań biblijnych z dosadnymi opisami początkowo nieśmiałego, a potem coraz bardziej zuchwałego odkrywania uroków i mroków świata gejowskiego. Prócz podobieństw na poziomie narracji oba przedstawienia łączy też ascetyczna scenografia. Miedziewski umieścił swojego księdza w skromnie urządzonej kancelarii parafialnej - właściwie składającej się tylko ze stołu i krzesła. Korytko postawił aktora w jeszcze bardziej wyeksponowanej pozycji, pozbawiając go możliwości ukrycia się lub podparcia jakimkolwiek rekwizytem. Jest tylko aktor, wpatrzona w niego widownia, pusta scena, smuga światła i wyczerpujący emocjonalnie tekst.

W słupskich Wyznaniach 32-letni ksiądz rozpoczyna swój dramatyczny monolog półnagi, z ręcznikiem owiniętym wokół bioder, jakby dopiero co wyszedł z sauny. Ta scena otwierająca - mimo swojej cielesności i przyziemności, bo sauna to też miejsce seksualnych schadzek - ma też budzić skojarzenia religijne i symbolizować „zmartwychwstanie” czy też odrodzenie tożsamości, gotowość na wejrzenie w siebie. Robi się ciemniej, młody duchowny nakłada czarne spodnie i sweter, a my stajemy się świadkami jego próby kazania, które nigdy nie zostanie wygłoszone. Co dziwi, bo przecież to, co ma do przekazania nie zaskakuje: że wśród księży są ho-mo-se-ksu-a-li-ści, którzy grzeszą myślą, mową, uczynkiem i zaniedbaniem; że piękni klerycy są mile widziani i faworyzowani w seminariach; że to problem pedofilii, a nie tzw. ideologii LBGTI, toczy Kościół katolicki. Trudno w tym przekazie doszukiwać się braku uczciwości i zacietrzewienia ideologicznego. Jak piszą na stronie Słupskiego Ośrodka Kultury twórcy monodramu (pisownia oryginalna), „nasz teatr wtrąca się w problem egzystencjalnego 
konfliktu między przestrzenią ducha i ucieleśnieniem natury ludzkiej a «OPRESJA TRADYCJ|». Owa opowieść «a Bóg lubi opowieści» jest zwierciadłem, w którym każdy może rozpoznać los bliźniego ....albo «rzucić kamieniem»".

W jednej osobie ogniskują się napięcia całej instytucji: ksiądz-gej staje się jej zakładnikiem i ofiarą, ale też współsprawcą jej systemowej skostniałości. Spowiada się przed nami z różnych perspektywklisz: ministranta ślicznego jak z obrazka, ulubieńca proboszcza i oczka w głowie nadopiekuńczej matki; niewinnego kleryka, który odkrywa swoją seksualność w Berlinie, w saunach i na czatach portalu Interia; młodego, przeżywającego kryzys wiary księdza, dzielącego się swoimi dylematami. Jest też druga, ciemniejsza strona przedzierająca się do monologu, dochodząca do głosu jak sumienie i kara: hierarchowie nawołujący do opamiętania i do zaprzestania interesowania się ich życiem prywatnym i seksualnym, bo na to monopol powinni mieć duchowni i sprzymierzeni z nimi ideologicznie politycy.

Psychoanalityczny klucz do odczytania spektaklu wydaje się być uzasadniony. Młody ksiądz jest targany namiętnościami (id) i ograniczany regułami (superego) opresyjnej instytucji i tradycji. Przez wciągający i momentami elektryzujący monolog przebija się kompromis między tymi skrajnościami. Aktor (Grzegorz Piekarski) nie mówi egzaltowanym, natchnionym, wytrenowanym w seminarium głosem znanym nam z kościelnych ceremonii, co tylko dodaje wygłaszanemu tekstowi autentyczności. Ponad dekadę temu, gdy wystawiano „Wściekłego psa”, odtwórca głównej roli - Kamil Frey - podobno przyznał, że ze strachu i świadomości podniosłości momentu trzęsły mu się nogi, a momentami nawet odczuwał ucisk w gardle.

Wydawałoby się, że dziesięć lat po tamtej premierze, w czasach dominującego w polityce nurtu katolicko-narodowego i systemowej nagonki na osoby LGBTI, nikt nie odważy się wystawić podobnego spektaklu z obawy o napiętnowanie w tzw. mediach narodowych. Jednak Piekarski, wygłaszając swój monolog w mieście, które swego czasu wybrało na prezydenta Roberta Biedronia i do dziś ma u władzy ludzi przyjaznych mniejszościom seksualnym, robi to bez kompleksów. Z jego monologu emanuje przekonanie, że warto skonfrontować się z perspektywą tęczowego księdza i wysłuchać kazania, które najpewniej długo jeszcze w polskim życiu pozateatralnym ciałem się nie stanie.

W przeważająco katolickim kraju takim jak Polska, gdzie rozdział państwa i kościoła jest fikcją, spektakle z perspektywy księży-gejów to wciąż nowatorskie zjawisko. W świecie pozateatralnym szerokim echem odbił się coming out Łukasza Kachnowicza, byłego księdza, a dziś aktywisty LGBTI, który w rozmowie z Marcinem Wójcikiem w „Dużym Formacie” z 9 września 2019 roku opowiadał o kulisach swojego odejścia z kapłaństwa: „napisałem do biskupa, że nie mogę żyć spokojnie w ukryciu, kiedy sypią się gromy na homoseksualistów". To mógł być moment przełomowy uruchamiający lawinę podobnych wyznań w Kościele katolickim, ale od czasu wywiadu żaden z duchownych nie poszedł śladem Kachnowicza. Można się jednak spodziewać, że w związku z postępującą w Polsce sekularyzacją, 
rosnącą liczbą osób dokonujących apostazji (wg nieoficjalnych źródeł, w 2020 roku tylko w kurii krakowskiej takiego aktu dokonało 445 osób) oraz kryzysem instytucji kościelnych temat kryzysu wiary księży-gejów będzie zamiast kontrowersji budził coraz większe zainteresowanie.

Premiera monodramu w wykonaniu Grzegorza Piekarskiego odbyła się 24 października 2020 roku w Ośrodku Teatralnym RONDO w Stupsku przy udziale widowni. Spektakl transmitowano też na żywo online 27 marca 2021 roku, by uczcić Międzynarodowy Dzień Teatru. Organizatorzy zapowiadaja kolejne wystawienia monodramu po zniesieniu obostrzeń związanych z pandemia. 